\title{
Research on the Significant Advantages of China's National System and National Governance System in Concentrating on Major Affairs
}

\author{
Qiangwei Zhou, Meng Li \\ Party School of the Sichuan Provincial Committee of the Communist Party of China, Chengdu, Sichuan
}

\begin{abstract}
Since the founding of the people's Republic of China 70 years ago, under the premise that the Chinese people choose the Communist Party of China and the firm political direction guarantee that the Chinese people unswervingly accept the leadership of the Communist Party of China, our party has led the people through arduous efforts and struggle to overcome and break through all kinds of difficulties and obstacles that hinder the progress and development of the Chinese nation. Our party led the diligent and life-loving Chinese people to create world-renowned achievements in rapid economic development and the oriental miracle of long-term social stability, enabling the once-suffering Chinese people to achieve a great leap from standing up, getting rich to becoming strong. These remarkable achievements are great historical practices and fully prove that the socialist system with Chinese characteristics and the national governance system have distinct Chinese characteristics. They are in line with the development direction of human civilization, and have a powerful system of vitality and great superiority. It is the system and governance system to promote China's economic and social progress and people's all-round development. Adhering to and leveraging the significant advantages of China's national system and national governance system, and gathering the strength of the entire people to do great things, is an inexhaustible source of power to ensure that the Chinese nation realizes the "two centenary" goals and realizes the great rejuvenation of the Chinese nation.
\end{abstract}

Keywords: Socialism with Chinese characteristics, National governance system, The rule of China.

\section{Introduction}

Since the founding of the Communist Party of China, after 100 years of joint struggle, creation and accumulation, the party and the people have opened up the road of socialism with Chinese characteristics, formed the theoretical system of socialism with Chinese characteristics, and established the socialist system with Chinese characteristics. As a scientific system, the system of socialism with Chinese characteristics is the true knowledge of the party and the people through historical practice. It is the summary of the achievements of Marxism in guiding China's construction and development and combining it with China's actual situation. It is the correct guidance and firm cornerstone to guide China's continuous development. It has brought nearly 1.4 billion regions, regions and regions into full play. The people of all ethnic groups are closely united and gathered around the Communist Party of China, giving full play to the strong organizational and practical mobilization power of the party leading the people, and concentrating the people's strength. Then, through the industrious and intelligent hands of the people, we can build the country under the centralized command of the party and the state, so as to ensure that "China will build a moderately prosperous society in an all-round way by 2020 On the basis of realizing the first Centennial goal, we will strive for another 15 years to basically realize socialist modernization in 2035 , and from 2035 to the middle of this century, we will strive for another 15 years to build China into a prosperous, strong, democratic, civilized, harmonious and beautiful socialist modern power.’[1]

\section{Adhering to the System of Socialism with} Chinese Characteristics is the Fundamental Guarantee to Support the Dynamic Operation of Concentrating on Major Tasks

2.1 The Basic Content of the System of Socialism with Chinese Characteristics

The system of socialism with Chinese characteristics includes the basic political system of the people's Congress system, the multi-party cooperation and political consultation system under the leadership of the Communist Party of China, the system of regional ethnic autonomy, and the system of grass-roots mass autonomy[2].

2.2 The Practical Basis of the System of People's Congress for China to Concentrate its Efforts on Major Affairs

The people's Congress system is a fundamental political system suitable for China's national conditions. It directly reflects the national nature of China's people's democratic dictatorship and is the basis for establishing the management system of other countries in China. Only the people's Congress system can ensure that the rights of the state are in the hands of the people, conform to the purpose of the people being the masters of the country, and suit China's national conditions. Its advantages are as follows.

It is conducive to ensuring state power and embodying the will of the people. First of all, "China is a socialist country under the people's democratic dictatorship led by the working class and based on the alliance of workers and peasants."[3] All power in the people's Republic of China belongs to the people, and the people are the masters of the country. All 
actions of the party and the state are guided by the interests of the people, and are aimed at realizing the fundamental interests of the people. Therefore, the people's Congress system, as the fundamental political system of our country, establishes all the principles of the state's power organ from the political and legal point of view, which comes from the collective will of the people. The state and the government only exercise part of the political power on behalf of the people, and the ultimate source of its political power is the people Secondly, the people's Congress system fundamentally unifies the interests of the people and the government in the fundamental principle. The purpose of all activities of the party and the government is to serve the people and seek the welfare of the people. State power embodies the will of the people. Therefore, the people can support the huge political organization operation system of the government, We will pool all social forces to carry out construction, do great things and do good deeds[4].

It is conducive to ensuring the unity of central and local state power. China is a vast country with a land area of about 9.6 million square kilometers, with 34 provincial administrative regions and a large longitude and latitude span. The geographical and ecological environment, human customs and regional history are different. According to the contradiction methodology of Marxist philosophy, both universality and particularity need to be paid attention to in order to achieve the dynamic balance of the unity of central and local powers. The people's Congress system fundamentally guarantees the unity of central and local state powers and the balance between the implementation of central universal power and the protection of local special rights and interests. That is to say, the central government makes unified arrangements for the construction and development strategy of the whole country for all national affairs. All local problems are subject to the fundamental and general policies of the state, and specific measures in line with the economic development of the region are formulated according to local conditions. This not only ensures the unified leadership of the central government, but also gives full play to the enthusiasm and innovation of the local governments, so that they can achieve an organic unity in the distribution of national political power.

It is conducive to ensuring the equality and unity of all ethnic groups in our country. China is a multi-ethnic country with 56 nationalities. In the long-term process of historical development, all ethnic groups in China have gradually merged into the Chinese nation, and the distribution of ethnic groups is mainly large mixed and small concentrated. At present, the distribution of population, resources and economic and cultural development in China are unbalanced. Only by implementing the system of people's congresses, and in accordance with the Constitution and the law, the people's congresses at all levels should be equipped with an appropriate number of minority representatives; Only by implementing regional ethnic autonomy and setting up organs of self-government in areas where ethnic minorities gather can ethnic minorities manage their own internal affairs, can they unite the people of all ethnic groups in the whole country, and let the people of all ethnic groups in the whole country hold together like pomegranate seeds, work together and forge ahead, which is conducive to the development of all ethnic groups and the prosperity of the country.

\subsection{The System of Multi-party Cooperation and Political Consultation under the Leadership of the Communist Party of China is the Realistic Basis for China to Concentrate its Strength on Major Affairs}

The system of multi-party cooperation and political consultation under the leadership of the Communist Party of China is deeply rooted in the soil of China, conforms to the development requirements of the cause of socialism with Chinese characteristics and the fundamental interests of the people of all ethnic groups in the country, and plays an extremely important role in China's economic and social development, showing great superiority and strong vitality.

The basic contents of the system of multi-party cooperation and political consultation under the leadership of the Communist Party of China include:

The Communist Party of China is the ruling party, the democratic parties are participating parties, and the Communist Party of China and the democratic parties are close comrades in arms. The Communist Party of China is in power on behalf of the people and controls and exercises state power on behalf of the people. Other democratic parties are participating parties, participating in state power, participating in the consultation of national policies and national leaders, participating in the management of state affairs, and participating in the formulation and implementation of national policies, laws and regulations.

The first prerequisite and fundamental guarantee for the cooperation between the Communist Party of China and the democratic parties is to adhere to the leadership of the Communist Party of China and the four basic principles. First, we must adhere to the socialist road; Second, we must uphold the dictatorship of the proletariat; third, we must uphold the leadership of the Communist Party; Fourth, we must adhere to Marxism Leninism and Mao Zedong thought.[5]

The basic principle of cooperation between the Communist Party of China and the democratic parties is: "long term coexistence, mutual supervision, mutual respect, sharing weal and woe."

The Communist Party of China and the democratic parties take the Constitution and laws as the fundamental principles of their activities.

The Chinese people's Political Consultative Conference (CPPCC) is an important organ of multi-party cooperation and political consultation under the leadership of the Communist Party of China. The CPPCC performs the functions of political consultation, democratic supervision and participation in the discussion of state affairs around the two themes of unity and democracy. 
The system of multi-party cooperation and political consultation under the leadership of the Communist Party of China has fundamentally ensured the exertion and practice of democratic politics. Through cooperation and consultation with other parties and non parties, our party has not only promoted the great development of social productive forces, but also promoted the continuous progress of society, Soliciting their suggestions and demands for the development and construction of the country, they finally formed the decision-making for the state to formulate scientific policies on the basis of democracy, and centralized leadership for other parties to achieve unity. In addition, democratic supervision, one of the functions performed by the CPPCC, greatly promotes the party and government departments at all levels to change their ideological and working styles, helps the Communist Party of China to continuously improve its ability to resist corruption and risks, supervises our party's ruling behavior, and makes suggestions on our party's ruling ability, so as to enhance and improve our party's ruling ability, To promote the scientific and correct ruling behavior of our party. China's multi-party cooperation and political consultation system is the unity of the diversity of organizational forms and the consistency of goals and directions. It is the unity of extensive democracy and centralized leadership. It is conducive to condensing the wisdom and strength of the whole society, forming a unified will, maximizing the concentration of social resources, and achieving efficient development.

\subsection{The Realistic Basis of the System of Regional National Autonomy for China's Concentrating on Major Affairs}

Under the unified leadership of the state, the system of regional ethnic autonomy refers to the practice of regional autonomy, the establishment of autonomous organs and the exercise of autonomy in areas inhabited by ethnic minorities.

China is a multi-ethnic country with 56 ethnic groups. In the long-term process of historical development, all ethnic groups in China have gradually merged into the Chinese nation. The ethnic groups are mainly large mixed and small concentrated. According to the bulletin on the main data of $1 \%$ of the national population released by the National Bureau of Statistics in 2015, the population of ethnic minorities in China is 117.35 million, accounting for $8.54 \%$, The Han population is 1256.14 million, accounting for $91.46 \%$. At the same time, there are imbalances in the distribution of population, resources and economic and cultural development. Therefore, only the implementation of the system of regional ethnic autonomy is conducive to the development of all ethnic groups and the prosperity of the country. In accordance with the Constitution and the law, there are an appropriate number of minority representatives in the people's congresses at all levels; Regional national autonomy should be implemented in areas where ethnic minorities gather, and organs of self-government should be set up to enable ethnic minorities to manage their own internal affairs. The implementation of regional national autonomy is not only in line with the historical development, but also in line with the actual situation, and has great advantages.
The system of regional ethnic autonomy is conducive to the maintenance of national unity and security. Regional ethnic autonomy is based on territorial integrity and national unity, and is the organic combination of centralized and unified leadership of the state and regional ethnic autonomy. It has strengthened the cohesion of the Chinese nation, and enabled the people of all ethnic groups, especially the ethnic minorities, to combine their deep love for their own nation with their deep love for the motherland, and to take on the glorious responsibility of defending the reunification of the motherland and the border areas more consciously.

Through the establishment of organs of self-government, ethnic minorities can manage the internal affairs of their own regions and nationalities, and guarantee the realization of the right of ethnic minorities to be masters of their own affairs[6].

Develop the socialist national relations of equality, unity, mutual assistance and harmony. Unite the people of all ethnic groups in China, let the people of all ethnic groups hold together like pomegranate seeds, work together, forge ahead, and promote the vigorous development of socialist modernization.

\subsection{The Practical Basis of the System of Grassroots Mass Autonomy for China's Concentrated Efforts to Do Great Things}

The system of mass autonomy at the grassroots level is a system of self-management, self-education, self-service and self supervision, which is composed of members elected by the residents (villagers) in accordance with the Constitution and the law[7].

The scope of the grass-roots mass autonomy system and the problems involved are closely related to the people's production and life, and related to the people's visible and tangible vital interests, so it is particularly important. Through direct election, the people elect the grass-roots mass self-government committee to exercise their rights and supervise the exercise of their rights, and directly participate in the management and supervision in the exercise process. It not only fully mobilized the enthusiasm and enthusiasm of the people to participate in political life, but also made democratic participation direct and effective, greatly enhancing the universality and authenticity of democracy.

Practice shows that the grass-roots mass autonomy in China is carried out under the scientific and correct guidance of the party and the government, which has better and directly solved the problem of the people's democratic development in our country, so that nearly 1.4 billion people can widely participate in the democratic political construction, and use their own strength to promote the healthy and orderly development of the democratic political construction, At the same time, it also strongly promotes the construction, development and progress of the country and society. As a basic content of China's political system, grassroots self-government system conforms to the trend of the times, conforms to the party's heart and the people's heart, and has a 
far-reaching impact on national development.

\section{Improving the Modernization of National Governance System and Governance Capacity Is the Power Source of Concentrating on Big Things}

\subsection{The Interpretation and Importance of the Modernization of National Governance System and National Governance Capacity}

The national governance system is the institutional system of the country under the leadership of the party, including the systems and mechanisms in various fields such as economy, politics, culture, society and ecology, forming a set of closely connected and mutually coordinated national systems, so as to realize the institutionalization, procedure and standardization of the whole society. The key measure to improve the national governance system is to reform the administrative system, economic system and social system, and realize the scientization of the three-level system of government, market and society[8].

The concept of national governance capacity is based on the national governance system, which reflects the level of using the national system to manage public affairs, including the ruling ability of the party, the executive ability of the government, the participation ability of social organizations and citizens, and the ability of social autonomy as a whole. The key to national governance ability lies in the continuous improvement of the government's ruling ability, the release of market vitality, the promotion and innovation of cultural soft power, the stimulation of the overall social potential and the good overall ecological quality, so as to make it fully respond to the changing world, national conditions and party conditions in the new era[9].

Since the 18th National Congress of the Communist Party of China, the party and the state have made a profound and scientific summary of the historical development at home and abroad, and scientifically evaluated and predicted the situation and new situation of China's development in the new era. It affirms the great achievements and achievements made in politics, economy, culture, science and other fields in the past 30 years of reform and opening up. These achievements and achievements are obtained through the unremitting struggle and efforts of the party and the people. In the new era, great changes have taken place both at home and abroad in China's development. The development opportunities and opportunities in the information age are changing rapidly, and China's economic development is also facing an important turning point. Therefore, in the new situation, it is particularly important and urgent to promote our country to make new major breakthroughs on the basis of the great achievements we have made. Looking for the "governance of China" under the leadership of the party to promote the modernization of China's national governance system and governance capacity is an important strategic choice to safeguard the fundamental interests and development of the country and the people in the new era.
3.2 The Modernization of National Governance System and Governance Capacity is the Concentrated Embodiment of a Country's System and System Implementation Capacity

According to incomplete statistics, comrade $\mathrm{Xi}$ Jinping mentioned more than 70 times of State Administration in public speeches and articles since the eighteen. The decision of the CPC Central Committee on several major issues of upholding and improving the socialist system with Chinese characteristics and promoting the modernization of national governance system and governance capacity, which was deliberated and passed at the Fourth Plenary Session of the 19th CPC Central Committee, systematically summarizes the advantages of China's national system and governance system, and makes major arrangements for further improving the national system and governance capacity. This fully demonstrates the determination and perseverance of the Party Central Committee with Comrade Xi Jinping as the core in improving the modernization of the state governance system and national governance capacity, and also provides new theoretical guidance and methodology options for improving the modernization of the national governance system and governance capacity. This indicates that while inheriting the theory of Sinicization of Marxism, our country constantly endows it with the spirit of innovation with the mission of the new era, and deeply embodies the CPC's deep understanding of the law of China's social development and its deep grasp of the "rule of China".

Comrade Xi Jinping has put forward in his nineteen major reports that China must adhere to the "eight clear" and "Fourteen adherence" in the new era in the perplexing international and domestic environment. From the theoretical and practical level, it answers that the process of modernization of national governance system and governance capacity is to adhere to and develop the road, system and strategy of socialism with Chinese characteristics[10].

\subsection{Marxism is the Theoretical Cornerstone of Adhering to and Playing the Role of China's National System and National Governance System}

To promote the modernization of national governance system and governance capacity, we must take Marxism as its theoretical basis, which is also the historical and practical foundation of the socialist system with Chinese characteristics. Since its birth in 1921, our party has unswervingly followed Marxism as the fundamental theory to guide Chinese revolution and construction. In different periods of history, our party has created specific models of Chinese revolution and construction in different periods according to Marxist theory and specific national conditions.

Therefore, adhering to the socialist system with Chinese characteristics is the fundamental premise to promote the modernization of national governance system and governance capacity, and also the most important behavior to improve the socialist system with Chinese characteristics and reflect the 
implementation capacity of the socialist system with Chinese characteristics. Only by constantly promoting and improving the modernization of the national governance system and governance ability can we fully show that the party's ability to lead the people to govern the country is advancing with the times, is constantly innovative, and is a new governance way and measures made according to the development of China in the new era.

\section{Constantly Transforming the Advantages of the Socialist System with Chinese Characteristics into the Efficiency of National Governance}

\subsection{It is the Internal Requirement of "The Rule of China" to Transform the System Advantage into Governance Efficiency}

The Fourth Plenary Session of the 19th CPC Central Committee stressed the need to "build a systematic, scientific, standardized and effective institutional system, strengthen systematic governance, legal governance, comprehensive governance and source governance, and better transform China's institutional advantages into national governance efficiency."

The key to the transformation of institutional advantages into governance effectiveness lies in implementation. With the continuous efforts of the party and the people and the continuous improvement of the socialist system with Chinese characteristics in the past 30 years of reform and opening up, the advantages of socialism with Chinese characteristics have been constantly displayed, and the national governance capacity has been constantly improved. The advantages of the socialist system with Chinese characteristics and the effectiveness of the national governance system are both showing the powerful power contained in it.

The governance of China means that since the founding of new China, the Chinese governance system and the road of Chinese governance under the leadership of the Communist Party of China have not wavered. In order to carry out the "rule of China", we must transform the advantages of the system into the powerful efficiency of the national governance ability to the greatest extent in the new era. Therefore, in view of the "hard bone" and "old and difficult" problems in the reform cause in the new era, we must adopt a systematic, scientific and effective system to strengthen its governance, and implement the advantages of the system into the implementation and core of the governance measures, which is the key to solve many problems in the reform.

\subsection{Adhering to the Party's Leadership is the Fundamental Guarantee to Transform the System Advantage into Governance Efficiency}

In the communique of the Fourth Plenary Session of the 19th CPC Central Committee, the word "system" was mentioned 77 times. In the new era, only scientific system can govern the country, and only scientific system can benefit the people. To transform the advantages of system into the efficiency of national governance and promote the modernization of national governance system and capacity, we must first implement it in the top-level design of national superstructure. The key lies in the party's leadership. China's national governance is under the party's leadership. The party's leadership is the most essential feature of socialism with Chinese characteristics and the greatest advantage of the socialist system with Chinese characteristics.

At the same time, the implementation of "the rule of China" must adhere to the leadership of the Communist Party of China" We must adhere to the principle of party, government, military and civilian studies, and the principle that the party leads everything in the East, West, North and south; We should firmly safeguard the authority of the Party Central Committee, improve the party's leadership system that takes charge of the overall situation and coordinates all parties, and implement the party's leadership in all fields and links of national governance; We should adhere to the party's highest political leadership, constantly improve the party's leadership system, and improve the party's level of scientific, democratic, and legal governance.

Only under the leadership of the party can the advantages of the socialist system with Chinese characteristics be shown to the greatest extent, and the country's stability be improved

The efficiency of governance has been improved to the greatest extent. Under the premise of adhering to the fundamental theory of Marxism, according to the changes of international external environment and domestic social development, the party makes full use of the Marxist concept of development and contradiction to reform and innovate the national governance system and mechanism, so as to make the national governance system and mechanism adapt to the development of the national economy at the present stage to the greatest extent and ensure the people's happy life.

We need to give full play to China's institutional advantages and enhance our confidence in road, theory, system and culture,

Adhere to self-improvement and transcendence, ensure the long-term effective operation of various systems, and make the society full of vitality and vitality of innovation and development.

\section{Conclusion}

The system of socialism with Chinese characteristics is the foundation of a country, which has fundamental, overall and directional guarantee for the design of national governance system and the improvement of national governance ability. National governance system is the systematic, institutional and theoretical guidance of national governance ability, especially for the improvement of national governance ability. National governance capability refers to the operation and implementation capability of the socialist system and national governance system with Chinese characteristics. It is the 
operation that the advantages of the national system and national governance system can be finally implemented. It can best reflect the implementation level and practical efficiency of national governance.

\section{References}

[1] Decisive victory to build a well-off society in an all-round way and win the great victory of socialism with Chinese characteristics in the new era[M]. Beijing: People's Publishing House, 2017.10.

[2] "Research on the Road to Chinese Governance" project group. Make governance more level-Promote the modernization of national governance system and governance capabilities[J]. Observation and Thinking, 2017 (01): 64-71.

[3] Guo Guangping. The connotation, significance and measures of promoting the modernization of the national governance system and governance capabilities[J]. Journal of the Party School of Shanxi Provincial Organs of the Communist Party of China, 2017 (02): 54-58.

[4] Decisive victory to build a well-off society in an all-round way and win the great victory of socialism with Chinese characteristics in the new era[M]. Beijing: People's Publishing House, 2017.10.

[5] "Research on the Road to Chinese Governance" project group. Make governance more level-Promote the modernization of national governance system and governance capabilities[J]. Observation and Thinking, 2017 (01): 64-71.

[6] "Research on the Road to Chinese Governance" project group. Make governance more level-Promote the modernization of national governance system and governance capabilities[J]. Observation and Thinking, 2017(01): 45-60.

[7] "Research on the Road to Chinese Governance" project group. Make governance more level-Promote the modernization of national governance system and governance capabilities[J]. Observation and Thinking, 2017 (01): 64-71.

[8] Du Feijin. A New Dimension of China's Modernization - On the Modernization of National Governance System and Governance Capability[J]. Social Science Research, 2014(05): 37-53

[9] Decisive victory to build a well-off society in an all-round way and win the great victory of socialism with Chinese characteristics in the new era[M]. Beijing: People's Publishing House, 2017.10.

[10] Xi Jinping presided over the first meeting of the 19th Central Committee for Comprehensively Deepening Reform Leading Group and emphasized fully implementing the spirit of the 19th National Congress of the Communist Party of China and unswervingly pushing the reform forward[J]. Beijing People's Congress, 2017 (12): 63-64.

\section{Author Profile}

Qiangwei Zhou, male, born in 1996, is a master's degree in 2019 of Sichuan provincial Party School of the Communist Party of China.

Meng Li, female, born in 1998, is a master's degree in 2020 of Sichuan provincial Party School of the Communist Party of China. 